\title{
EVALUASI HEURISTIK WEBSITE BERBASIS FRAMEWORK SIRIUS DENGAN PENGATURAN PRIORITAS MENGGUNAKAN TEKNIK MOSCOW
}

\author{
Gita Indah Marthasari*1, Nur Hayatin ${ }^{2}$ \\ ${ }^{1,2}$ Universitas Muhammadiyah Malang \\ Email: ${ }^{1}$ gita@umm.ac.id, ${ }^{2}$ noorhayatin@umm.ac.id \\ *Penulis Korespondensi
}

(Naskah masuk: 17 Januari 2019, diterima untuk diterbitkan: 06 Februari 2020)

\begin{abstract}
Abstrak
Kualitas merupakan faktor utama kesuksesan sebuah website. Salah satu karakteristik kualitas perangkat lunak menurut ISO 9126 adalah usabilitas. Pengukuran usabilitas sebuah website adalah hal yang penting mengingat sangat besarnya jumlah website saat ini. Salah satu metode yang dapat digunakan untuk mengevaluasi usabilitas website adalah framework Sirius. Sirius dapat menghasilkan nilai usabilitas global dan daftar elemen antarmuka sistem yang perlu diperbaiki. Namun, elemen-elemen ini belum diatur berdasarkan prioritas pengembang sistem dan hanya mempertimbangkan nilai peningkatan yaitu prosentasi perbaikan nilai usabilitas global jika elemen tersebut diperbaiki. Untuk itu dibutuhkan sebuah teknik untuk memprioritaskan elemen-elemen tersebut berdasarkan sudut pandang pengembang sistem sehingga sesuai dengan sumber daya yang dimiliki oleh pihak pengembang. Salah satu teknik yang dapat digunakan adalah Moscow. Moscow dapat mengelompokkan seluruh kebutuhan ke dalam 4 (empat) kelas berdasarkan tingkat prioritasnya. Penelitian ini melakukan modifikasi terhadap framework Sirius dengan menambahkan tahap perangkingan menggunakan teknik Moscow. Berdasarkan hasil pengujian, penambahan tahap pengaturan prioritas dengan Teknik Moscow memberikan urutan kriteria usability yang lebih baik dalam hal nilai bisnis, resiko, dan biaya pembangunan website. Setiap tim pengembang website yang dianalisis memberikan hasil pengaturan prioritas Moscow yang berbeda-beda. Bagi tim website Lective, kriteria usability paling penting adalah berkaitan dengan aspek labelling, sedangkan bagi pengembang website Seminar Indonesia, aspek paling penting adalah kelompok comprehensibility and ease of interaction. Adapun pengembang website Simkesmas lebih menekankan pada aspek control and feedback.
\end{abstract}

Kata kunci: kualitas perangkat lunak, evaluasi usability, evaluasi heuristic, framework Sirius, Teknik Moscow, perangkingan, website

\begin{abstract}
Quality became the key element for website deployment. Based on the ISO 9126, one of the quality characteristics in software engineering is usability. The usability measurement on a website is an essential topic nowadays along with the incremental growth of it. One of the evaluation methods that can be used for analysing website usability is Sirius Framework. This method can produce global usability values and the list of a user interface element that should be modified. However, those elements have not been adjusted based on developer priority system which only considers the increased value of each element - the percentage of modified global usability value. Therefore, A technique called MoSCoW was introduced for prioritizing those elements from a developer point of views which corresponds to its available resource. MoSCoW can categorize all of the requirements into 4 distinct classes based on priority. This paper was performed for extending the Sirius Framework for implementing the ranking system by using MoSCoW. The experiment results showed that the MoSCoW method for priority adjustment process could produce better usability criteria on business, risk, and cost value during website development.
\end{abstract}

Keywords: software quality, usability evaluation, heuristic evaluation, Sirius framework, Moscow technique, prioritization website

\section{PENDAHULUAN}

Kualitas adalah salah satu kunci kesuksesan sebuah website. Kualitas didefinisikan sebagai sekelompok karakteristik dari sebuah perangkat lunak yang menunjukkan kemampuan perangkat lunak tersebut dalam memenuhi kebutuhan pengguna (Behkamal, Kahani and Kazem, 2009)(Parsazadeh et al., 2018). Salah satu karakteristik kualitas perangkat lunak menurut ISO 9126 adalah usabilitas. Usabilitas diartikan sebagai sekumpulan atribut yang mampu menunjukkan seberapa besar usaha untuk menggunakan perangkat lunak dan evaluasi penggunaannya oleh pengguna spesifik. Usabilitas mencakup tiga sub-faktor yaitu kemampuan dipahami (understandability), kemampuan dipelajari (learnability), dan kemudahan operasional (operability).

Pengukuran usabilitas sebuah website adalah hal yang penting mengingat sangat besarnya jumlah 
website saat ini. Hampir segala bidang kehidupan telah menggunakan website untuk otomatisasi proses-proses yang berlangsung. Sebagian besar website tersebut sangat bermanfaat bagi pengguna. Namun, usabilitas yang kurang baik mengakibatkan pengguna mengalami penurunan motivasi, frustasi, dan membuang-buang waktu (Torrente et al., 2013)(Parsazadeh et al., 2018). Pengukuran atau evaluasi usabilitas adalah metode untuk mengukur aspek-aspek usabilitas dari sebuah antarmuka dan mampu mengidentifikasi persoalan-persoalan terkait. Evaluasi ini menjadi salah satu elemen penting dalam pembuatan antarmuka pengguna karena menjadi salah satu faktor penentu kesuksesan sebuah sistem berbasis web.

Salah satu metode yang dapat digunakan untuk mengevaluasi usabilitas website adalah Sirius. Sirius adalah sebuah framework evaluasi usabilitas yang bersifat heuristic dan pengukurannya menyesuaikan dengan jenis website. Evaluasi menggunakan framework Sirius dilakukan oleh pakar yang meliputi sekumpulan kriteria dan metrik usabilitas untuk menghasilkan sebuah nilai yang menunjukkan tingkat usabilitas website. Kelebihan framework ini antara lain mampu mendeteksi kesalahan usabilitas dari sudut pandang pakar, menggunakan aspek dan kriteria yang komprehensif dalam mengukur usabilitas, dan mampu menghasilkan sebuah nilai usabilitas global secara kuantitatif sebuah website sesuai dengan jenisnya. Luaran dari Sirius adalah kriteria-kriteria ideal website dan tingkat usabilitas tiap kriteria tersebut yang diurutkan berdasarkan potensi perbaikan yang diberikan jika kondisi ideal dari tiap kriteria tersebut tercapai yang disebut dengan increased value. Luaran ini diharapkan menjadi umpan balik bagi pihak pengembang website untuk memperbaiki antarmuka penggunanya. Kriteria-kriteria ini dapat dikatakan merupakan kebutuhan (requirement) bagi sistem. Banyaknya kriteria yang dinilai dalam framework Sirius dapat menyulitkan pihak pengembang untuk menentukan kebutuhan mana yang harus dipenuhi dalam sebuah versi perangkat lunak. Selain itu, ada beberapa kriteria yang memiliki nilai usabilitas yang sama sehingga menyulitkan pihak pengembang untuk menentukan prioritasnya. Penentuan prioritas dari keseluruhan fitur yang perlu diperbaiki merupakan hal yang penting mengingat tidak seluruh kebutuhan dapat diimplementasikan karena adanya keterbatasan sumber daya, anggaran, dan jumlah programmer ahli yang dimiliki (Bebensee, Van De Weerd and Brinkkemper, 2010)(Achimugu et al., 2014). Meskipun luaran dari Sirius telah diurutkan berdasarkan nilai increased value, namun nilai ini belum mewakili pertimbangan lain dalam penentuan prioritas seperti biaya dan waktu.

Salah satu teknik untuk mengatur prioritas kebutuhan adalah MoSCow. Teknik ini pertama kali digunakan pada salah satu metodologi pembangunan perangkat lunak berbasis agile-modelling yaitu
DSDM (Dynamic Software Development Method) (Waters, 2013). Kelebihan MoSCoW adalah mudah dan cepat dalam mengurutkan daftar kebutuhan serta mampu menghasilkan urutan yang akurat (Hatton, 2007). Teknik ini mengelompokkan seluruh kebutuhan ke dalam 4 (empat) kelas berdasarkan tingkat prioritasnya.

Pada penelitian terdahulu (Kusuma, Noviasari and Marthasari, 2016), telah dilakukan pengukuran usabilitas sebuah website yaitu sistem KRS Online di Universitas Muhammadiyah Malang. Pada penelitian ini metode yang digunakan dalam evaluasi adalah USE Questionnaire. Metode ini meliputi 3 (tiga) aspek yaitu usefulness, ease of use, dan ease of learning. Namun, penelitian ini belum menghasilkan nilai kuantitatif usabilitas dan elemen-elemen yang perlu diperbaiki dari sistem. Penelitian lain terkait evaluasi heuristik telah dilakukan oleh Bella, dkk (Mustikaningtiyas, Saputra and Pinandito, 2016). Sistem yang diuji adalah website Universitas Brawijaya dan metode yang digunakan adalah PostStudy System Usability Questionnaire (PSSUQ). Dalam penelitian tersebut, tidak ada kriteria standar untuk tiap aspek usability yang dievaluasi.

Khajouei, dkk (Khajouei, Gohari and Mirzaee, 2018) membandingkan dua metode evaluasi heuristik yaitu metode penilaian berdasarkan standar usability dan metode checklist dimana disediakan seperangkat kriteria usability yang sesuai dengan prinsip-prinsip usability Nielsen. Dari penelitian ini, diperoleh kesimpulan bahwa hasil evaluasi yang lebih baik diperoleh dari metode checklist dimana metode ini dapat digunakan oleh evaluator yang terbatas pengetahuan dan pengalaman dalam penilaian usability.

Beirekdar, dkk (Beirekdar, Vanderdonckt and Noirhomme-fraiture, 2002) telah mengusulkan sebuah bahasa, framework, dan prototype untuk evaluasi usabilitas website secara otomatis. Framework ini menggunakan pedoman-pedoman perancangan usabilitas yang diformalisasi ke dalam bahasa definisi tingkat tinggi yang terstruktur. Pedoman yang digunakan dalam penelitian tersebut adalah EvalWeb. Kriteria dalam pedoman selanjutnya distrukturisasi dalam format XML yang kemudian dijadikan acuan oleh program HTML parser untuk melakukan evaluasi usabilitas secara otomatis. Dengan menggunakan framework ini dapat diketahui elemen-elemen mana pada website yang belum memenuhi pedoman perancangan. Namun, framework ini belum mampu menghasilkan nilai usabilitas global website. Yeung, dkk (Yeung and Law, 2004) telah mengusulkan sebuah framework untuk mengevaluasi usabilitas website hotel. Penelitian ini melakukan modifikasi terhadap teknik evaluasi usabilitas heuristik untuk membandingkan kinerja antara hotel tunggal dan hotel-hotel yang tergabung dalam sebuah rantai. Terdapat 5 elemen yang dievaluasi yaitu bahasa, tata letak dan grafis, 
arsitektur informasi, antarmuka dan navigasi, serta usabilitas umum.

Tabel 1. Tinjauan Pustaka tentang Evaluasi Usability Website

\begin{tabular}{l} 
Metode Evaluasi \\
Usability \\
\hline \multicolumn{1}{c}{ Metode USE } \\
$\begin{array}{l}\text { Questionnaire Kusuma, } \\
\text { Noviasari and Marthasar } \\
\text { 2016) }\end{array}$ \\
Evaluasi heuristik \\
(Mustikaningtiyas, Saputra \\
and Pinandito, 2016) \\
Metode checklist (Khajouei, \\
Gohari and Mirzaee, 2018) \\
\\
Framework yang otomatis \\
mengevaluasi usability \\
(Beirekdar, Vanderdonckt \\
and Noirhomme-fraiture, \\
2002)
\end{tabular}

Framework usability untuk website hotel (Yeung and Law, 2004)

Framework untuk menilai accessability dan usability website open course (Rodríguez et al., 2017)

Menggunakan metode standard checklist dan survei untuk evaluasi usability website.(Pant, 2015)

Metode evaluasi usability secara heuristik dengan pendekatan kultural. (Diaz, Collazos and Rusu, 2016)

Evaluasi menggunakan model usability Shackel's. (Hussain, Nainar and Salam, 2014)

Menggunakan perangkat lunak Site Analyzer dan Qualidator untuk mengevaluasi website. (Kaur, Kaur and Kaur, 2016)

Belum ada kriteria standar untuk tiap aspek usability yang dievaluasi.

Membandingkan metode standard usability dan metode checklist . Metode checklist dinilai lebih baik karena metode ini dapat digunakan oleh evaluator yang terbatas pengetahuan dan pengalaman dalam penilaian usability.

Framework ini menggunakan pedoman-pedoman perancangan usabilitas yang diformalisasi ke dalam bahasa definisi tingkat tinggi yang terstruktur. Pedoman yang digunakan dalam penelitian tersebut adalah EvalWeb.

Merupakan modifikasi terhadap teknik evaluasi usabilitas heuristik untuk membandingkan kinerja antara hotel tunggal dan hotel-hotel yang tergabung dalam sebuah rantai.

Framework ini dikembangkan dari framework Sirius yang disesuaikan dengan kriteria website open course.

Metode ini digunakan untuk mengevaluasi website perpustakaan di berdasarkan 6 aspek usability yaitu usefulness, efficiency, effectiveness, learnability, satisfaction, dan accessability.

Metode diterapkan untuk mengevaluasi website ecommerce. Terdapat 12 kriteria usability berorientasi budaya yang digunakan sebagai standar evaluasi.

Digunakan untuk mengevaluas website e-learning. Sejumlah responden dilibatkan baik yang sudah pernah maupun yang belum pernah menggunakan website tersebut.

Digunakan untuk mengevaluas website resmi universitas. Site Analyzer untuk evaluasi konten, rancangan, dan kinerja sistem, sedangkan Qualidator untuk mengevaluasi usability, accessability, dan kualitas teknik.

Framework ini dapat menghasilkan kinerja usabilitas website secara umum. Namun, belum ada bukti yang menunjukkan bahwa framework ini dapat diterapkan terhadap jenis website selain web hotel.
Rodriguez, dkk (Rodríguez et al., 2017) mengusulkan sebuah framework untuk mengevaluasi accessibility dan usability website materi sekolah terbuka (open course ware / OCW). Framework ini dikembangkan dari framework Sirius yang disesuaikan dengan kriteria website OCW. Selain itu, terdapat kriteria tambahan yang termasuk dalam aspek accessibility dimana Sirius hanya menilai aspek usability. Perbandingan penelitian terkait dapat dilihat pada Tabel 1.

Berdasarkan uraian dalam latar belakang, dapat disimpulkan bahwa dibutuhkan sebuah teknik penentuan prioritas kriteria perbaikan yang dihasilkan oleh framework Sirius. Salah satu teknik penentuan prioritas adalah MoSCoW. Oleh karena itu, masalah penelitian ingin diselesaikan adalah (1) Bagaimana menggabungkan framework Sirius dan teknik MoSCoW untuk memperoleh urutan kebutuhan perbaikan sistem? (2) Bagaimana menguji performa penggabungan framework Sirius dan teknik MoSCoW?

\section{METODE PENELITIAN}

Menurut ISO 9241-11, usabilitas perangkat lunak menyatakan kemampuan sebuah perangkat untuk digunakan oleh pengguna dan konteks spesifik dalam mencapai tujuan spesifik secara efektif, efisien, dan memuaskan (Torrente et al., 2013), (Rodríguez et al., 2017). Evaluasi usabilitas website selalu dibutuhkan sebagai sebuah usaha untuk memberikan layanan yang baik bagi pengguna. Manfaat evaluasi ada 3 yaitu 1) memberikan umpan balik bagi perbaikan rancangan, 2) menilai apakah sasaran telah tercapai, dan 3) memantau penggunaan sistem selama beberapa waktu. Terdapat 3 elemen usability yaitu efektivitas, efisiensi, dan kepuasan pengguna.

Framework Sirius adalah sebuah alat evaluasi usabilitas website yang berbasis penilaian heuristic (Torrente et al., 2013). Model framework ditunjukkan pada Gambar 1. Sirius memiliki 10 aspek penilaian (Tabel 2) dan masing-masing aspek memiliki subkriteria sehingga total kriteria yang ada adalah 83 item. Framework ini mampu menghasilkan nilai usabilitas global berdasarkan penilaian para pakar sekaligus memberikan informasi tentang kesalahan usabilitas dari website berdasarkan jenisnya. Informasi ini berguna bagi pihak pengembang website untuk memperbaiki antarmukanya.

Dalam penelitian ini dilakukan modifikasi terhadap Framework Sirius dengan menambahkan Teknik Moscow untuk perangkingan. Hasil modifikasi selanjutnya diuji untuk mengetahui kontribusi perangkingan terhadap luaran dari evaluasi usability. Rancangan Framework Sirius yang dimodifikasi dengan penambahan Teknik Moscow dapat dilihat pada Gambar 2. 


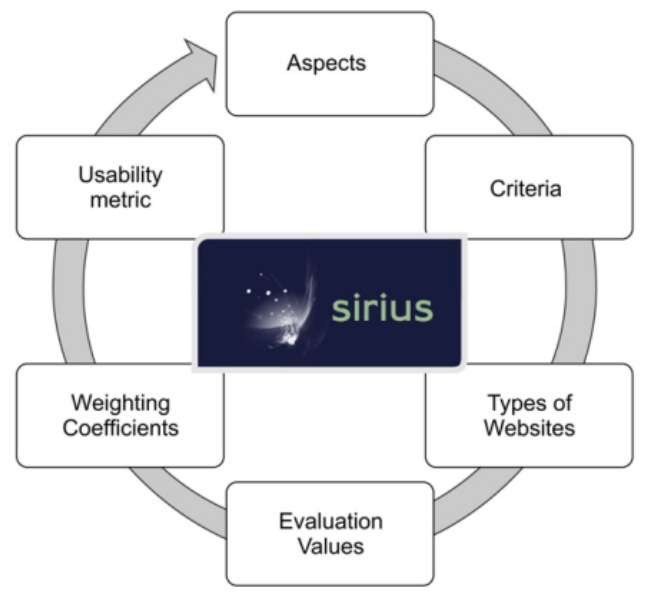

Gambar 1. Framework Sirius

Tabel 2. Aspek Usability Framework Sirius

\begin{tabular}{ll}
\hline \multicolumn{1}{c}{ Aspek } & Keterangan \\
\hline General Aspects (GA) & Menilai tujuan website, look and \\
& $\begin{array}{l}\text { feel, koherensi, dan tingkat } \\
\text { update website. }\end{array}$ \\
Indentity dan & Menilai identitas dan informasi \\
Information (II) & pemilik \\
Structure dan & Menilai kecukupan informasi \\
Navigation (SN) & tentang navigasi website \\
Labelling (LB) & Menilai pelabelan konten \\
Layout of the Page & Menilai tata letak tampilan \\
(LY) & website \\
Comprehensibility dan & Menilai kualitas konten teks, \\
Ease of Interaction & ikon, dan pengaturan antar \\
(CI) & muka. \\
Control dan Feedback & Menilai fleksibilitas navigasi \\
(CF) & \\
Multimedia Elements & Menilai ketersediaan multimedia \\
(ME) & di website \\
Search (SE) & Menilai fitur pencarian di \\
& website \\
Help (HE) & Menilai ketersediaan fitur \\
& bantuan di website \\
\hline
\end{tabular}

Tabel 2. Tingkat Prioritas pada Teknik Moscow

\begin{tabular}{ll}
\hline \multicolumn{1}{c}{ Tingkat Prioritas } & \multicolumn{1}{c}{ Deskripsi } \\
\hline Must Have & $\begin{array}{l}\text { Fitur yang harus ada dan } \\
\text { ketiadaannya menyebabkan } \\
\text { kegagalan sistem. }\end{array}$ \\
Should Have & $\begin{array}{l}\text { Fitur yang sebaiknya ada } \\
\text { Could Have }\end{array}$ \\
& $\begin{array}{l}\text { Fitur yang sebaiknya ada tapi } \\
\text { manfaatnya kurang dari fitur pada } \\
\text { kategori 'S' }\end{array}$ \\
& $\begin{array}{l}\text { Fitur yang tidak harus ada namun } \\
\text { dapat diimplementasikan jika ada } \\
\text { kelebihan anggaran. }\end{array}$ \\
\hline
\end{tabular}

MoSCoW merupakan akronim dari 4 tingkatan prioritas yaitu Must Have, Should Have, Could Have, dan Want to Have (Barritt, 2002; Hatton, 2007). MoSCoW merupakan sebuah aturan untuk mengelompokkan kebutuhan perangkat lunak sehingga pihak pengembang mengetahui kebutuhan mana yang harus diimplementasikan dan yang mana yang sebagai pelengkap. Kelebihan teknik ini adalah mudah digunakan dan mampu memberikan prioritas yang akurat. Penjelasan lengkap dari tiap tingkatan ditunjukkan pada tabel 2 .

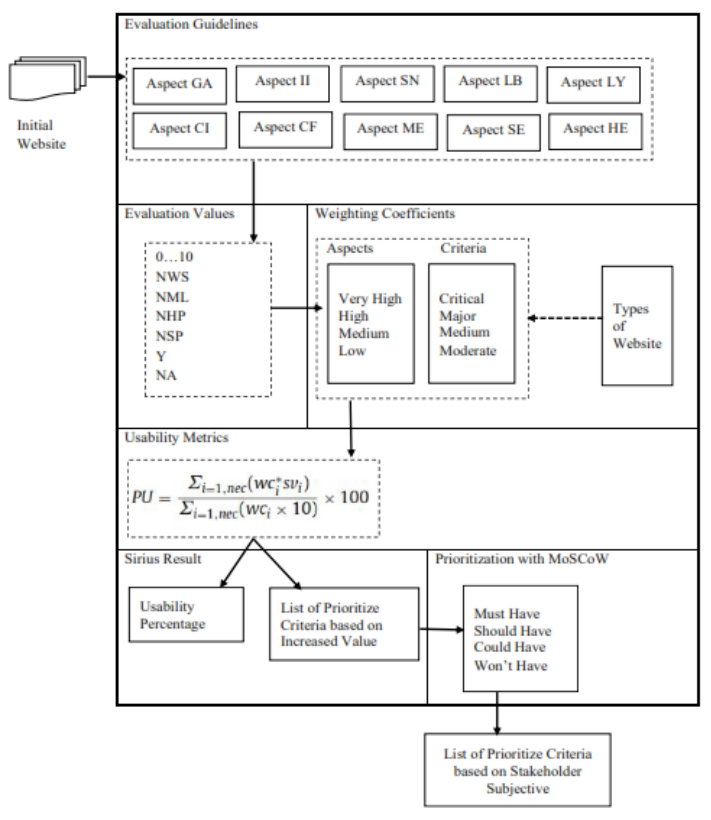

Gambar 2. Framework Sirius dengan penambahan Teknik Perangkingan Moscow berikut :

Langkah-langkah penelitian adalah sebagai

a. Studi Pustaka

Mencari dan mempelajari literatur tentang website usability evaluation, framework Sirius, dan teknik pengaturan prioritas MoSCoW.

b. Modifikasi Framework Sirius

Menggabungkan framework Sirius dengan teknik MoSCoW. Adapun rencana framework modifikasi adalah seperti pada Gambar 2. Kontribusi penelitian terletak pada penambahan proses penentuan prioritas dengan teknik MoSCoW. Berdasarkan gambar tersebut, langkahlangkah evaluasi website adalah sebagai berikut :

1) Penilaian oleh pakar terhadap website berdasarkan kriteria-kriteria yang termasuk dalam evaluation guidelines. Seluruh kriteria dikelompokkan menjadi 10 aspek. Kesepuluh kriteria ini diturunkan menjadi 83 item penilaian. Pakar memberikan nilai terhadap 83 kriteria tersebut. Kriteria pakar adalah orang yang minimal pernah menjadi perancang antarmuka 2 website berbeda dan website tersebut berstatus selesai dan dapat diakses secara online pada saat penelitian berlangsung. 
2) Nilai dari pakar selanjutnya dibobot berdasarkan aspek dan kriteria serta mempertimbangkan jenis dari website.

3) Untuk mendapatkan nilai usabilitas global, hasil pembobotan dimasukkan ke dalam perhitungan usability metrics. Setelah selesai, akan dihasilkan nilai usabilitas global dan daftar elemenelemen yang harus diperbaiki. Daftar ini telah diurutkan berdasarkan nilai increased value yaitu prosentase peningkatan usabilitas global sistem jika elemen tersebut diperbaiki.

4) Kriteria atau elemen yang harus diperbaiki selanjutnya diatur prioritasnya menggunakan teknik Moscow dengan memasukkan tiap elemen ke salah satu kriteria Moscow. Hasilnya adalah daftar elemen yang harus diperbaiki yang telah dikelompokkan berdasarkan prioritas Moscow.

c. Pengujian Hasil Modifikasi

Pengujian framework hasil modifikasi dilakukan sebagai berikut :

1) Pengujian dilakukan terhadap 3 website berbeda yang jenisnya sama dan masing-masing dinilai oleh 5 orang pakar. Salah satu website dalam status pengembangan dan dua lainnya berstatus selesai. Penilaian seluruh pakar dihitung menggunakan langkahlangkah pada framework Sirius.

2) Survey hasil perangkingan kepada tim pembangun website untuk mengetahui relevansi hasil terhadap resiko, biaya, dan nilai bisnis.

\section{MODIFIKASI FRAMEWORK SIRIUS}

\subsection{Pemilihan Website Uji}

Website yang digunakan dalam proses analisis yaitu LECTIVE (https://www.lective.id/), KINETIK (http://kinetik.umm.ac.id/index.php/kinetik), dan SEMINAR INDONESIA ( http://seminarindonesia.id/ ). Ketiga website ini masuk dalam kategori pendidikan.

\section{a. LECTIVE}

Merupakan website pendidikan yang membantu dosen-dosen di perguruan tinggi dalam menyusun kurikulum program studi . Lective terbagi menjadi 2 jenis aplikasi yaitu Lective Gegulang dan Lective Huluakan. Lective Huluakan merupakan system yang membantu penyusunan kurikulum program studi. Lective Gegulang merupakan system yang membantu perancangan rencana pembelajaran per semester (RPS) dan rencana pembelajaran per pertemuan (RPP).

Dalam kaitan dengan penyusunan kurikulum, setiap program studi di perguruan tinggi harus mampu menyusun dan mengorganisasi kurikulum baik untuk kemudahan akses data maupun proses belajar-mengajar (PBM). Berdasarkan hasil pengamatan, belum ada sistem yang khusus bertujuan mengelola kurikulum mulai dari pengisian, perubahan, penyimpanan, dan pencarian data kurikulum per program studi. Fitur-fitur ini disediakan oleh website Lective Huluakan.

Menurut Peraturan Pemerintah (PP) nomor 32 tahun 2013 yang merupakan penyempurnaan dari PP nomor 19 tahun 2005, RPS dan RPP merupakan penyajian dari perencanaan pelaksanaan proses pembelajaran untuk setiap muatan pembelajaran (Indonesia, 2013). Dokumen-dokumen ini wajib disiapkan oleh setiap dosen di perguruan tinggi sebagai pedoman proses belajar-mengajar. Namun, dalam prakteknya, sebagian besar dosen mengalami kesulitan menyusun RPS/RPP. Berdasarkan pengamatan, belum ada system yang membantu dosen dalam menyusun dan mengelola RPP/RPS.

Sistem Lective menjadi sangat vital perannya di perguruan tinggi, mengingat pentingnya proses pengelolaan kurikulum dan RPP/RPS di program studi. Pengukuran usability terhadap system Lective Gegulang pernah dilakukan oleh Marthasari, dkk (Marthasari and Hayatin, 2017). Model yang digunakan untuk pengukuran adalah use questionnaire. Berdasarkan penelitian tersebut, diperoleh hasil bahwa usability Lective Gegulang masuk dalam kategori layak. Namun, dalam model use questionnaire tidak menilai komponen-komponen teknis dari antarmuka pengguna. Hal ini yang menjadi latar belakang disertakannya sistem Lective sebagai objek penelitian.

\section{b. SIMKESMAS}

SIMKEMAS merupakan salah satu contoh sistem informasi (SI) berbasis web di bidang kesehatan. SI di bidang ini memegang peran penting dalam meningkatkan efisiensi dan efektivitas pengelolaan data-data kesehatan. Website ini mulai digunakan sejak tahun 2016. SIMKESMAS merupakan sebuah sistem online sebagai penunjang layanan kesehatan dengan bertujuan memudahkan proses administrasi dan pelayanan puskesmas lainnya (https://simkesmas.com). Melalui SIMKESMAS, pasien maupun calon pasien dapat memperoleh informasi dan layanan secara real time antara lain terkait dengan monitoring dan controlling sesuai dengan pelaksanaan pelayanan puskesmas. Dalam website ini juga disediakan fitur form layanan UKP (Upaya Kesehatan Perorangan) dan UKM (Upaya Kesehatan Masyarakat), laporan bulanan, laporan 
bahan habis pakai dan obat-obatan, serta data statistik yang bermanfaat untuk monitoring kesehatan masyarakat secara real time. Semua fitur yang disediakan website SIMKESMAS meliputi keseluruhan aspek kebutuhan puskesmas sehingga petugas kesehatan yang ada dapat lebih fokus pada pelayanan dan pemeriksaan pasien. Sampai saat ini, belum banyak penelitian yang mengevaluasi tingkat usability website SIMKESMAS.

\section{SEMINAR INDONESIA}

Website SEMINARINDONEISA (http://seminarindonesia.id) merupakan sebuah sistem pengelolaan seminar. Fitur-fitur yang ditanamkan di dalam sistem antara lain pengelolaan kegiatan seminar meliputi pengelolaan makalah dan peserta oleh pengelola seminar dan fitur pengelolaan makalah dan pembayaran bagi peserta seminar. Sampai saat ini, penelitian tentang usability website SEMINARINDONESIA belum pernah dilakukan.

\subsection{Pengujian menggunakan Framework Sirius}

Evaluasi heuristic adalah penilaian oleh sejumlah evaluator terhadap user interface yang mengacu pada sejumlah aturan yang berlaku. Dalam penelitian ini, evaluator adalah para pakar di bidang user interface dengan kriteria : evaluator adalah dosen yang pernah atau sedang mengampu mata kuliah bidang interaksi manusia dan komputer atau menekuni bidang penelitian tersebut, dan praktisi yang keahliannya pada bidang tersebut. Untuk menentukan jumlah evaluator, Torrente, et.al (Torrente et al., 2013) menyarankan sebanyak minimal 5 evaluator yang terlibat dalam penilaian. Oleh karena itu, evaluator yang dilibatkan dalam penelitian ini adalah 4 orang dosen dan 1 orang praktisi industri.

Pada penelitian ini, evaluasi dilakukan menggunakan tools yaitu website Prometheus (http://prometheus-usability.com). Proses diawali dengan menyiapkan form penilaian bagi ketiga website yang akan diuji. Adapun konfigurasi yang harus diatur adalah URL website, deskripsi, dan tipe website. Berikut adalah skenario evaluasi oleh evaluator :

1. Evaluator diminta untuk membuka ketiga website yang akan dievaluasi dengan diberikan username dan password untuk dapat melakukan login ke sistem.

2. Evaluator diminta untuk mencoba seluruh fitur yang ada pada sistem.

3. Evaluator mengisi form evaluasi tiap website yang telah disediakan secara online.

4. Pada saat proses evaluasi berlangsung, peneliti dapat memberikan instruksi atau penjelasan terkait item-item yang dievaluasi.

\subsection{Penerapan Teknik Moscow}

Salah satu luaran dari evaluasi menggunakan Framework Sirius adalah daftar kriteria usability yang belum terpenuhi oleh website dan daftar ini bisa berbeda tergantung evaluator. Sebelum dikelompokkan menggunakan Teknik Moscow, perlu dilakukan agregasi dari hasil penilaian seluruh evaluator. Pertimbangan dalam melakukan agregasi adalah bahwa meskipun evaluator memiliki tingkat kepakaran yang berbeda-beda, persoalan usability yang ditemukan oleh evaluator dianggap merupakan persoalan yang memang perlu diperbaiki dari website. Hal ini karena persoalan usability yang besar bisa saja ditemukan oleh evaluator yang tingkat kepakarannya "rendah" (Nielsen and Molich, 1990). Oleh karena itu, seluruh kriteria yang digunakan dalam perhitungan akan dimasukkan ke dalam pengaturan dengan Moscow. Pada penelitian ini, pengaturan prioritas dilakukan oleh perwakilan dari pihak pemangku kepentingan proyek yaitu pimpinan tim. Pimpinan tim akan diberikan sebuah form yang berisi kriteria-kriteria usability yang masing-masing harus ditentukan prioritasnya.

\section{HASIL DAN PEMBAHASAN}

\subsection{Hasil Evaluasi menggunakan Frameworks Sirius}

Untuk website Simkesmas, dari 5 orang evaluator, rata-rata penilaian seluruh evaluator terhadap website adalah sebesar $57.65 \%$. Penilaian terendah adalah sebesar $37.3 \%$ dimana nilai tersebut menunjukkan sejauh mana aspek usability diimplementasikan dalam website SIMKESMAS. Adapun nilai tertinggi dari evaluator adalah sebesar $85.63 \%$ dimana nilai ini menyatakan bahwa sebagian besar aspek usability telah diterapkan. Jika menggunakan Framework Sirius, prosentase persoalan usability dapat diukur dari prosentase usability global. Jika rata-rata usability global untuk website SIMKESMAS adalah $57.65 \%$ maka persoalan usability yang ditemukan adalah sebesar 42.75\% (=100\% $57.65 \%$ ). Beragamnya penilaian evaluator terhadap website yang diuji disebabkan oleh berbeda-bedanya tingkat kepakaran evaluator. Hasil evaluasi untuk website Lective menunjukkan nilai global usability-nya sebesar $63.56 \%$ yang berdasarkan kategori pada tabel 8 termasuk "layak". Dengan demikian, besarnya persoalan usability website yang menunjukkan banyaknya item usability yang perlu diperbaiki sebesar 36.44\%. Adapun evaluasi terhadap website Seminar Indonesia menunjukkan nilai global usability sebesar $69.61 \%$ yang berdasarkan kategori pada tabel 3 termasuk "layak". Dengan 
demikian, besarnya persoalan usability website yang menunjukkan banyaknya item usability yang perlu diperbaiki sebesar $30.39 \%$.

Tabel 3. Standar Penilaian Usability Sistem (Marthasari and Hayatin, 2017)

\begin{tabular}{ll}
\hline \multicolumn{1}{c}{ Tingkat Prioritas } & \multicolumn{1}{c}{ Deskripsi } \\
\hline nilai $<21$ & Sangat tidak layak \\
$21 \leq$ nilai $\leq 40$ & Tidak layak \\
$40 \leq$ nilai $\leq 60$ & Cukup \\
$60 \leq$ nilai $\leq 80$ & Layak \\
$80 \leq$ nilai $\leq 100$ & Sangat layak \\
\hline
\end{tabular}

\subsection{Hasil Evaluasi Luaran Framework Sirius yang diurutkan menggunakan Teknik Moscow}

Berdasarkan hasil pengaturan prioritas oleh perwakilan setiap tim developer website yang dianalisis, diperoleh hasil bahwa pengaturan prioritas Moscow terhadap masing-masing website berbedabeda. Hal ini menunjukkan bahwa pertimbangan dalam menentukan prioritas juga berbeda meskipun faktor-faktor yang dipertimbangkan sama yaitu biaya, resiko, dan nilai bisnis. Adapun bobot dan definisi dari tiap faktor pertimbangan diserahkan kepada pihak penentu prioritas dalam hal ini perwakilan tim developer.

Untuk mengetahui kriteria mana saja dari ke-83 kriteria Framework Sirius yang dianggap paling penting (must have) pada tiap website, dilakukan penghitungan jumlah kriteria yang termasuk kriteria "must have". Grafik pemetaan per website ditunjukkan pada gambar 3. Dari gambar tersebut diperoleh kesimpulan bahwa untuk website Lective, kelompok kriteria usability paling penting adalah berkaitan dengan aspek labelling yaitu pelabelan konten. Sedangkan bagi pengembang website Seminar Indonesia, aspek paling penting adalah kelompok comprehensibility and ease of interaction yaitu terkait dengan kualitas konten teks, ikon, dan pengendalian antarmuka. Adapun pengembang website Simkesmas lebih menekankan pada aspek control and feedback yaitu terkait dengan navigasi dan ketersediaan informasi selama interaksi user.

Gambar 3. Grafik Prosentasi Kriteria Usability Paling Penting (a) Website Lective (b) Seminar Indonesia (c) Simkesmas.

Selain itu, peneliti juga melakukan survey kepada pengembang website terkait kontribusi perangkingan menggunakan Teknik Moscow. Itemitem yang disurvey adalah relevansi hasil perangkingan terhadap aspek resiko, biaya, dan kebutuhan bisnis. Pihak yang dilibatkan dalam survey adalah pimpinan tim pembangunan website. Hasilnya menyatakan bahwa kriteria-kriteria usability yang telah diurutkan menggunakan Teknik Moscow memberikan gambaran bagi tim developer dalam menentukan kriteria yang paling relevan dalam aspek resiko, biaya, dan kebutuhan bisnis.

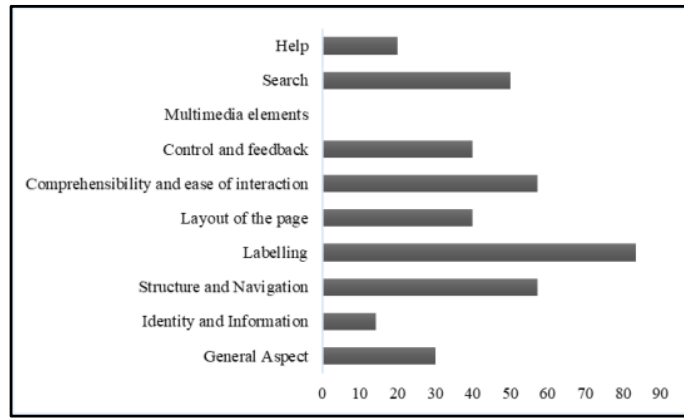

(a)

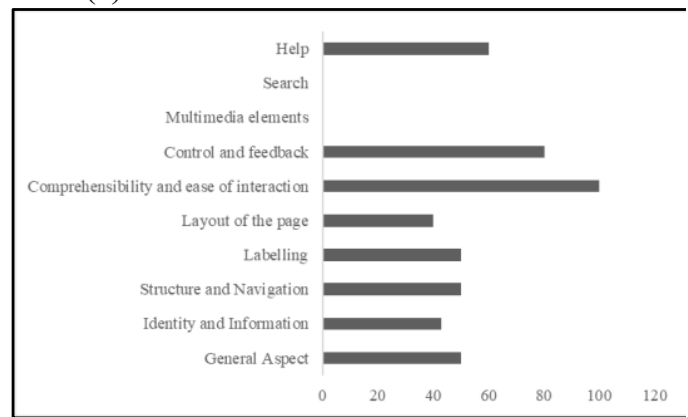

(b)

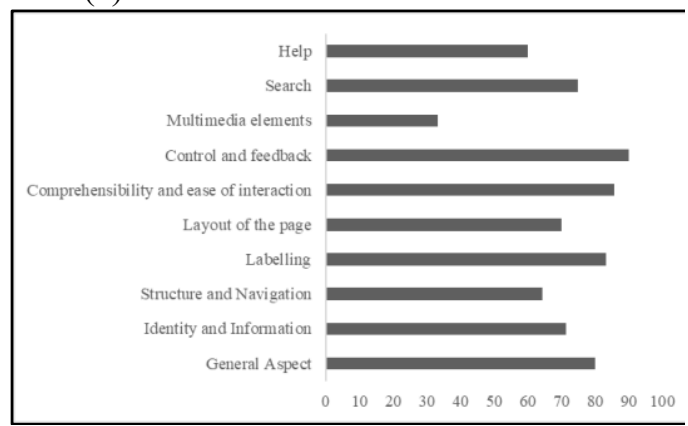

(c)

\section{SIMPULAN}

Salah satu metode pengukuran usability website adalah Framework Sirius. Penelitian ini melakukan modifikasi terhadap framework tersebut dengan menambahkan Teknik Moscow dalam pengaturan prioritas perbaikan aspek usability. Berdasarkan pelaksanaan dan evaluasi diperoleh kesimpulan bahwa penambahan proses perangkingan terhadap tahap-tahap evaluasi usability memberikan urutan hasil kriteria usability yang lebih baik yaitu relevan terhadap aspek resiko, biaya, dan nilai bisnis bagi client. Kesimpulan lain yang diperoleh yaitu bahwa evaluasi dengan Frameworks Sirius menghasilkan aspek-aspek usability yang belum terpenuhi oleh website. Hasilnya dapat digunakan sebagai rekomendasi bagi pengembang website baik selama proses pembangunan maupun setelahnya. Mengingat keterbatasan penelitian antara lain jumlah evaluator, tingkat kepakaran evaluator, maka pengembangan penelitian ini dapat berupa evaluasi oleh beberapa kelompok evaluator dengan tingkat kepakaran yang berbeda-beda. Penelitian di masa mendatang juga dapat terkait analisis pengaruh evaluasi usability terhadap hasil akhir website. 


\section{DAFTAR PUSTAKA}

ACHIMUGU, P. et al. (2014) 'A systematic literature review of software requirements prioritization research', Information and Software Technology. Elsevier B.V., 56(6), pp. 568-585. doi: 10.1016/j.infsof.2014.02.001.

BARRITT, D. (2002) 'IEC 61131 and DSDM in Real-Time Process Control Applications', Computing and Engineering Journal, (April), pp. 94-100.

BEBENSEE, T., VAN DE WEERD, I. AND BRINKKEMPER, S. (2010) 'Binary priority list for prioritizing software requirements', Lecture Notes in Computer Science (including subseries Lecture Notes in Artificial Intelligence and Lecture Notes in Bioinformatics), 6182 LNCS, pp. 67-78. doi: 10.1007/978-3-642-14192-8_8.

BEHKAMAL, B., KAHANI, M. AND KAZEM, M. (2009) 'Customizing ISO 9126 quality model for evaluation of B2B applications', Information and Software Technology, 51, pp. 599-609. doi: 10.1016/j.infsof.2008.08.001.

BEIREKDAR, A., VANDERDONCKT, J. AND NOIRHOMME-FRAITURE, M. (2002) 'A Framework and a Language for Usability Automatic Evaluation of Web Sites by Static Analysis of HTML Source Code', Proceedings of 4 th International Conference on Computer-Aided Design of User Interfaces, 59(2002), pp. 337-348.

DIAZ, J., COLLAZOS, C. A. AND RUSU, C. (2016) 'Experimental Validation of a Set of Cultural-Oriented Usability: e-Commerce Websites Evaluation', Computer Standards \& Interfaces. Elsevier, 50(December 2017), pp. 160-178. doi: 10.1016/j.csi.2016.09.013.

HATTON, S. (2007) 'Early Prioritisation of Goals', Advances in Conceptual Modeling Foundations and Applications, 4802, pp. 235-244. doi: 10.1007/978-3-540-76292829.

HUSSAIN, M., NAINAR, M. AND SALAM, A. (2014) 'Students' Assessment on the Usability of E -learning Websites', Procedia Social and Behavioral Sciences, 141, pp. 916-922.

doi: 10.1016/j.sbspro.2014.05.160.

INDONESIA, P. R. (2013) Peraturan Pemerintah RI Nomor 32 Tahun 2013 tentang Standar Nasional Pendidikan. Indonesia. Available at: http://kelembagaan.ristekdikti.go.id/wpcontent/uploads/2016/08/PP0322013.pdf.

KAUR, S., KAUR, K. AND KAUR, P. (2016) 'Analysis of Website Usability Evaluation
Methods', in 2016 International Conference on Computing for Sustainable Global Development (INDIACom). New Delhi.

KHAJOUEI, R., GOHARI, S. H. AND MIRZAEE, M. (2018) 'Comparison of two heuristic evaluation methods for evaluating the usability of health information systems', Journal of Biomedical Informatics, 58, pp. 97-111. doi: 10.1016/j.jbi.2018.02.016.

KUSUMA, W. A., NOVIASARI, V. AND MARTHASARI, G. I. (2016) 'Analisis Usability dalam User Experience pada Sistem KRS- Online UMM menggunakan USE Questionnaire', JNTETI, 5(4), pp. 294-301.

MARTHASARI, G. I. AND HAYATIN, N. (2017) 'ANALISIS USABILITY TERHADAP SISTEM LECTIVE GEGULANG', in Seminar Nasional Teknologi dan Rekayasa. Malang, pp. 1-8.

MUSTIKANINGTIYAS, B. A., SAPUTRA, C. M. AND PINANDITO, A. (2016) 'ANALISIS USABILITY PADA WEBSITE UNIVERSITAS BRAWIJAYA DENGAN HEURISTIC EVALUATION', Jurnal Teknologi Informasi dan Ilmu Komputer, 3(3), pp. 188-193.

NIELSEN, J. AND MOLICH, R. (1990) 'HEURISTIC EVALUATION', in CHI Proceedings, pp. 249-256.

PANT, A. (2015) 'Usability evaluation of an academic library website: Experience with the Central Science Library University of Delhi', The Electronic Library, 33(5).

PARSAZADEH, N. et al. (2018) 'The construction and validation of a usability evaluation survey for mobile learning environments', Studies in Educational Evaluation. Elsevier, 58(May), pp. 97-111. doi: 10.1016/j.stueduc.2018.06.002.

RODRÍGUEZ, G. et al. (2017) 'A framework for improving web accessibility and usability of Open Course Ware sites', Computers and Education. Elsevier Ltd, 109, pp. 197-215. doi: 10.1016/j.compedu.2017.02.013.

TORRENTE, M. C. S. et al. (2013) 'Sirius: A heuristic-based framework for measuring web usability adapted to the type of website', Journal of Systems and Software, 86(3), pp. 649-663. doi: 10.1016/j.jss.2012.10.049.

WATERS, K. (2013) Prioritization using MoSCoW.

YEUNG, T. A. AND LAW, R. (2004) 'Extending the modified heuristic usability evaluation technique to chain and independent hotel websites', International Journal of Hospitality Management, 23(3), pp. 307313. doi: 10.1016/j.ijhm.2003.03.001. 